OPEN ACCESS

Edited by:

Ana M. Queiros,

Plymouth Marine Laboratory,

United Kingdom

Reviewed by:

Maickel Armenteros,

National Autonomous University of Mexico, Mexico

Roman N. Zajac,

University of New Haven,

United States

*Correspondence:

Katherine Dunlop

katherine.mary.dunlop@hi.no

Specialty section:

This article was submitted to

Marine Ecosystem Ecology,

a section of the journal

Frontiers in Marine Science

Received: 02 June 2020

Accepted: 29 October 2020

Published: 30 November 2020

Citation:

Dunlop K, Harendza A, Plassen L and Keeley N (2020) Epifaunal Habitat

Associations on Mixed and Hard Bottom Substrates in Coastal Waters

of Northern Norway.

Front. Mar. Sci. 7:568802.

doi: 10.3389/fmars.2020.568802

\section{Epifaunal Habitat Associations on Mixed and Hard Bottom Substrates in Coastal Waters of Northern Norway}

\author{
Katherine Dunlop ${ }^{1 *}$, Astrid Harendza ${ }^{2}$, Liv Plassen ${ }^{3}$ and Nigel Keeley ${ }^{1}$ \\ ${ }^{1}$ Institute of Marine Research, FRAM - High North Research Centre for Climate and the Environment, Tromsø, Norway, \\ ${ }^{2}$ Akvaplan-niva, FRAM - High North Research Centre for Climate and the Environment, Tromsø, Norway, ${ }^{3}$ Marine Geology, \\ Geological Survey of Norway, Trondheim, Norway
}

Hard and mixed seafloor substrates are an important benthic habitat in coastal northern Norway and they are known to be colonized by relatively diverse communities of sessile epifauna. These assemblages are highly susceptible to physical damage and stresses imposed by organic material from industrial and municipal sources. However, despite increasing prevalence of stressors, the diversity and distribution of benthic substrates and biological communities in coastal Arctic and sub-Arctic regions remain poorly documented. In response, this study has characterized the composition of mixed and hard bottom substrates and associated sessile epifauna in fjords in Finnmark, northern Norway, using remote sensing and an innovation low-cost towed camera method. The study fjords supported a dense covering (0.1 to 0.68 individuals $\left.\mathrm{m}^{-2}\right)$ of sponge taxa common to deep-water ostur sponge habitats (Geodia sp., Mycale lingua, Polymastia sp., Phakellia ventilabrum, and Axinella infundibuliformis). In addition, aggregations of the soft coral (Duva florida), the tunicate (Ascidia sp.), the seastar (Ceramaster granularis) and anemone (Hormathia digitata) were prominent fauna. The small-scale spatial patterns of the epifaunal communities in this study were primarily influenced by the local hydrodynamic regime, depth, the topographical slope and the presence of hard bedrock substrates. This description of the composition, distribution and the identification of environmental drivers of epibenthic communities is valuable for the development of predictive habitat models to manage the benthic impact of multiple stressor on these ecological valuable and vulnerable Arctic habitats.

Keywords: Arctic, benthic epifauna, ecological mapping, sponges, video surveys

\section{INTRODUCTION}

Coastal Arctic and sub-Arctic regions are experiencing a combination of multiple stressors from industrial activities (commercial fishing, aquaculture, marine shipping and mining), municipal expansion and climatic change. Furthermore, warming and opening Arctic seas are contributing to an expansion in these maritime activities in the Arctic (Jentoft and Buanes, 2005; Aanesen et al., 2018; Olsen et al., 2019). In particular, growth of the Norwegian fin-fish aquaculture industry is projected to continue (Anon, 2014-2015), especially in sub-Arctic fjords in Northern Norway 
where space is available (Skarôhamar et al., 2018). Waste discharges from industrial and municipal sources (i.e., organic input from fin-fish aquaculture, disposal of mine tailings and municipal waste) and benthic trawling are known to increase sedimentation and resuspension in benthic systems and can have a range of adverse impacts on benthic habitats and communities (Burd et al., 2013; Ramirez-Llodra et al., 2015; Bannister et al., 2016). Marine spatial management in the coastal zone is essential to prevent seafloor environmental degradation and species or habitat loss that can result from anthropogenic uses, as specified in the Biodiversity Convention, Habitat Directive and the Marine Strategy Framework Directive (UN, 1992; Evans, 2006; Long, 2011; Buhl-Mortensen and Buhl-Mortensen, 2014). Good comprehension of the diversity and spatial distribution of marine habitats and associated taxa is essential for effective marine spatial planning and to minimize the impact of anthropogenic pressure on marine habitats (Harris and Whiteway, 2009; Buhl-Mortensen et al., 2012). However, despite increasing pressure from multiple stressors, the spatial distribution of benthic habitats in coastal inshore waters in northern Norway are poorly documented, making coastal zone management in the area difficult.

Although semi-protected, the fjords and coastlines in northern Norway tend to be steep-sided and can have relatively strong currents, two environmental factors associated with hard benthic substrates (Wahl, 2009). These bottom types are typically comprised of solid bedrock, boulders, cobbles and gravel, often interspersed with patches of coarse soft-sediments. Indeed, hard and mixed seafloor substrate are known to characterize many Arctic and sub-Arctic coastal regions (Boertmann et al., 2009; Glud et al., 2010; Buhl-Mortensen et al., 2017). Hard and mixed substrates provide a habitat with high structural complexity and heterogeneity, and topographical relief that have been associated with enhanced species diversity and richness (Howell et al., 2016). These substrates are commonly colonized by kelp forests, seaweed fringes, eelgrass, maerl beds, coral and sponge aggregations and rich animal turf communities, many of which have been recognized for their high biodiversity and provision of multiple ecosystem services (Kamenos et al., 2004; Christie et al., 2009; Mineur et al., 2015). Subtidal hard bottom substrates are typically colonized by sessile invertebrates, such as sponges, bryozoans, cnidarians and ascidians (Wenner et al., 1983; Hamoutene et al., 2015).

Studies on and at the margins of the Norwegian continental shelf, that extend 200 nautical miles from the shore and covers a water depth range between 20 and 2,000 $\mathrm{m}$ (Klitgaard and Tendal, 2004; Buhl-Mortensen et al., 2012) have shown that deep-sea sponge grounds and biogenic reefs formed by cold-water corals are dominant communities on hard substrates. In recognition of their ecological importance and vulnerability to anthropogenic disturbance, sponge grounds and cold-water coral habitats and their associated communities in Arctic and sub-Arctic deep-sea waters have been designated as Vulnerable Marine Ecosystems (VMEs) (Buhl-Mortensen et al., 2019). Despite the recognized importance of these hard substrates to epifaunal communities in northern regions, knowledge on the diversity and distribution of these habitats and communities in coastal inshore waters (extending 12 nautical miles from the coastline) in Arctic and sub-Arctic regions is lacking. Furthermore, knowledge on the spatial distribution of these communities is increasingly important with rapid anthropogenic development in these areas.

The paucity of information about these coastal inshore habitats is partly a result of the challenges associated with conducting effective surveys around physical and biological structures. Hard and mixed substrates form structurally complex and inherently patchy distributions, and associated epifaunal species generally have a naturally low abundance which presents difficulties for the quantification of species and identification of spatial patterns (Hamoutene et al., 2016; Meyer et al., 2019). This challenge is compounded when depths are below normal SCUBA diving limits $(<30 \mathrm{~m})$. While remotely operated vehicles (e.g., Lacharité and Metaxas, 2017) or large imaging platforms (e.g., CAMPOD: Buhl-Mortensen and Buhl-Mortensen, 2014) have been used effectively to survey epifaunal assemblages in deepsea environments their application to inshore coastal waters is limited. These survey systems are high cost (i.e., $>\$ 100,000$ USD), large and difficult to maneuver around complex bathymetry and must be operated from a large vessel which usually prohibits sampling close to shore or in proximity to structures such as marine fish farms. Moreover, maintenance is expensive and considerable technical expertise is required for operation and support.

Relatively low-cost drop cameras with reduced technical specification are effective for the fine-scale analysis of abundance, diversity and distribution of epifaunal communities in inshore coastal waters (Salvo et al., 2017, 2018). However, this method is limited in its spatial coverage, both in terms of the practicality of raising and lowering a camera over long distances and quadrat size (usually $<1 \mathrm{~m}^{2}$ ), which is inappropriate to survey sparsely distributed organisms (Magurran and McGill, 2011). Towed camera systems are, however, capable of surveying a larger area than drop cameras and thus provide a solution for larger spatial scale surveys. Towed camera systems have provided quantitative surveys of inshore sessile epifaunal communities on a spatial scale suitable to determine community spatial variability and detect influential environmental variables. For example, a deep-sea towed camera system was used to examine megaepifaunal invertebrate communities and environmental drivers in topographically complex habitats (cold seep and hydrothermal vents) between 700 and $1500 \mathrm{~m}$ (Bowden et al., 2016). Also, the distribution patterns of temperate subtidal rocky reefs in shallow waters (10 to $40 \mathrm{~m}$ ) in the south-western Baltic Sea were quantified using a towed camera system (Beisiegel et al., 2018).

In response to the lack of data on the diversity and spatial distribution of hard and mixed seafloor substrates and associated epifaunal communities, this study applied a novel towed video survey technique combined with remote sensing to effectively characterize: (1) the substrate composition of patchy mixed and hard bottom habitats and (2) the associated sessile epifauna communities in poorly mapped coastal northern Norway. Of specific interest is determining the fine-scale associations of the primary epifaunal assemblages with benthic substrate cover characteristics and other environmental variables. Furthermore, this study presents a novel and cost-effective towed video camera technique and footage analysis method for the quantitative 
survey of epifaunal communities on complex hard and mixed topography in inshore coastal waters.

\section{MATERIALS AND METHODS}

\section{Site Description and Sampling Design}

Study sites were situated in areas of mixed and hard substrate in Finnmark, northern Norway (Figure 1A). Substrate type and associated epifaunal assemblages were surveyed at five fjord sites in October 2017. Detailed surveys were conducted at these sites in Øksfjorden $\left(70.1-70.2^{\circ} \mathrm{N} ; 22.3-22.5^{\circ} \mathrm{E}\right)$ and Vargsundet $(70.2-$ $70.4^{\circ} \mathrm{N}, 23.2-23.7^{\circ} \mathrm{E}$ ) (Figure 1B). In Øksfjorden, sites were located on the western coast adjacent to Klubbnesvika and on the eastern coast offshore from Rosenby (Figure 1C). Surveys sites in Vargsundet were located at the southern shore and in the center of Bekkarfjorden $\left(70.3445^{\circ} \mathrm{N}, 23.4015^{\circ} \mathrm{E}\right)$, and along the eastern shore of Vargsundet, north of Lerresfjorden $\left(70.3235^{\circ} \mathrm{N}\right.$, $23.4332^{\circ} \mathrm{E}$ ) (Figure 1D). All surveys sites were more than $1 \mathrm{~km}$ from aquaculture operations for Atlantic salmon (Salmo salar) and were consider unaffected by aquaculture waste material or other sources of anthropogenic pollution. Survey transects of $\sim 500 \mathrm{~m}$ were sampled parallel to the coastline along 70 and $100 \mathrm{~m}$ depth contours in both Øksfjorden and Vargsundet. Survey site details are provided in Table $\mathbf{1}$ and video transect details in Supplementary Table 1.

\section{Bathymetry and Substrate Mapping}

The wider area in the vicinity of the study sites was surveyed initially by the Geological Survey of Norway (NGU) using a combination of multibeam echosounder, Topas (sediment echosounder), video surveys and grabs from the RV Seisma to resolve the seafloor substrate structure. In addition, multibeam data were provided from Kartverket. Multibeam data provided high resolution bathymetry maps and subsequently formed the base for the development of substrate maps ( $5 \mathrm{~m}$ resolution), which were ground-truthed by results from video and grab samples. Each grab sample that adequately penetrated the sediment was sub-sampled and analyzed for sediment grain size. Bathymetric and substrate data was processed in ArcMap version 10.6 (ESRI Inc, 2018) to create maps that were used to plan the epifaunal video transects to ensure that they covered a range of mixed and hard bottom substrate types and followed the designated depth contours. The video transect tracks were also overlaid onto the substrate map in ArcMap.

\section{Hydrodynamic Site Characteristics}

Current velocities in the survey area during October 2017 were simulated using the Regional Ocean Modeling System (ROMS ${ }^{1}$ ) (Shchepetkin and McWilliams, 2005; Haidvogel et al., 2008, see text footnote 1). The ROMS model grid was forced along the open boundaries of the larger-scale coastal model, NorKyst800 (Albretsen et al., 2011). The model has a grid resolution of $160 \mathrm{~m} \times 160 \mathrm{~m}$ and generates hourly data on the EW and NS component of the horizontal current flows throughout the water

${ }^{1}$ http://myroms.org column. The near-bottom currents that were extracted for use in this study were between 1 and $2 \mathrm{~m}$ above the seafloor. The average current velocity recorded during October 2017 from both the EW and NS component dimension was extracted from the modelled data for each transect.

\section{Video Transects}

Towed video camera transects were conducted from the RV Fangst at an average speed over ground of $0.3 \mathrm{~m} \mathrm{~s}^{-1}$ ( \pm st.dev 0.03). A GoPro Hero 4 mounted on a towed underwater video system (UVS) recorded HD video footage of the seabed (Figure 2). The field of view was illuminated by two Keldan $4 \mathrm{X}$ video lights $(9000 \mathrm{~lm})$ and scaled by two Sea Beam ${ }^{\mathrm{TM}}$ Laser Scalers with parallel lines separated by $7 \mathrm{~cm}$. The two lasers were mounted in an angle such that the two pairs of lines crossed at the bottom of the picture when the camera was at the desired distance above the seabed (ca. $1 \mathrm{~m}$ ). A Splashcam Delta Vision industrial underwater video camera (1/3" $960 \mathrm{H}$ High Sensitivity CCS, > 750 TVL) provided a live feed video from the UVS to an onboard monitor via a $250 \mathrm{~m}$ cable. The live feed allowed for safe navigation over the seafloor, whilst the cable was used to manually maneuver (raise and lower) the UVS. The positioning of video transects was continually recorded by the vessel's Geographical Positioning System (GPS) and subsequently used to calculate (a) distance to farm ('as the crow flies') and (b) accumulative distance traveled along the seabed (using basic trigonometry), thereby allowing for track sinuosity. Both distance measures were overlaid on to the highresolution GoPro.mov files (along with position, date and time) using freely available DashWare 1.9 software to facilitate sample area calculations.

\section{Video Transect Annotation}

For the analysis of video sequences, transects were initially subdivided into $40 \mathrm{~m}$ sections. A substantial change in the field of view or a new substrate type, however, also initiated the start of a new section. The seafloor area sampled by each section ( 5 to $150 \mathrm{~m}^{-2}$, hereafter termed a 'swath') was calculated by multiplying swath length (distance traveled over ground) by the average swath width. Swath width was determined by scaling the field of view with the aid of two lasers with paired lines (set at $7 \mathrm{~cm}$ apart) at two or three points along each swath (start, middle and end). Within each swath unit, the percentage coverage of primary, secondary and tertiary substrate types were recorded. Substrate types were classified into eight categories; (1) solid bedrock, (2) patchy bedrock/broken reef, (3) boulders, (4) broken rocks, (5) gravel and cobbles, (6) shellsand, (7) sand, and (8) gravelly sand (Supplementary Table 2). Slope estimates were allocated to each swath and were based on five visually discernable categories; (1) flat, (2) moderate, (3) steep, (4) near-vertical, and (5) overhang. In addition, all distinguishable epifaunal taxa that entered the frame of view were enumerated. Benthic taxa were identified to the lowest achievable taxonomic level and their abundance was determined. Taxonomically similar epifauna, which could not be distinguished with confidence, were grouped into descriptive 


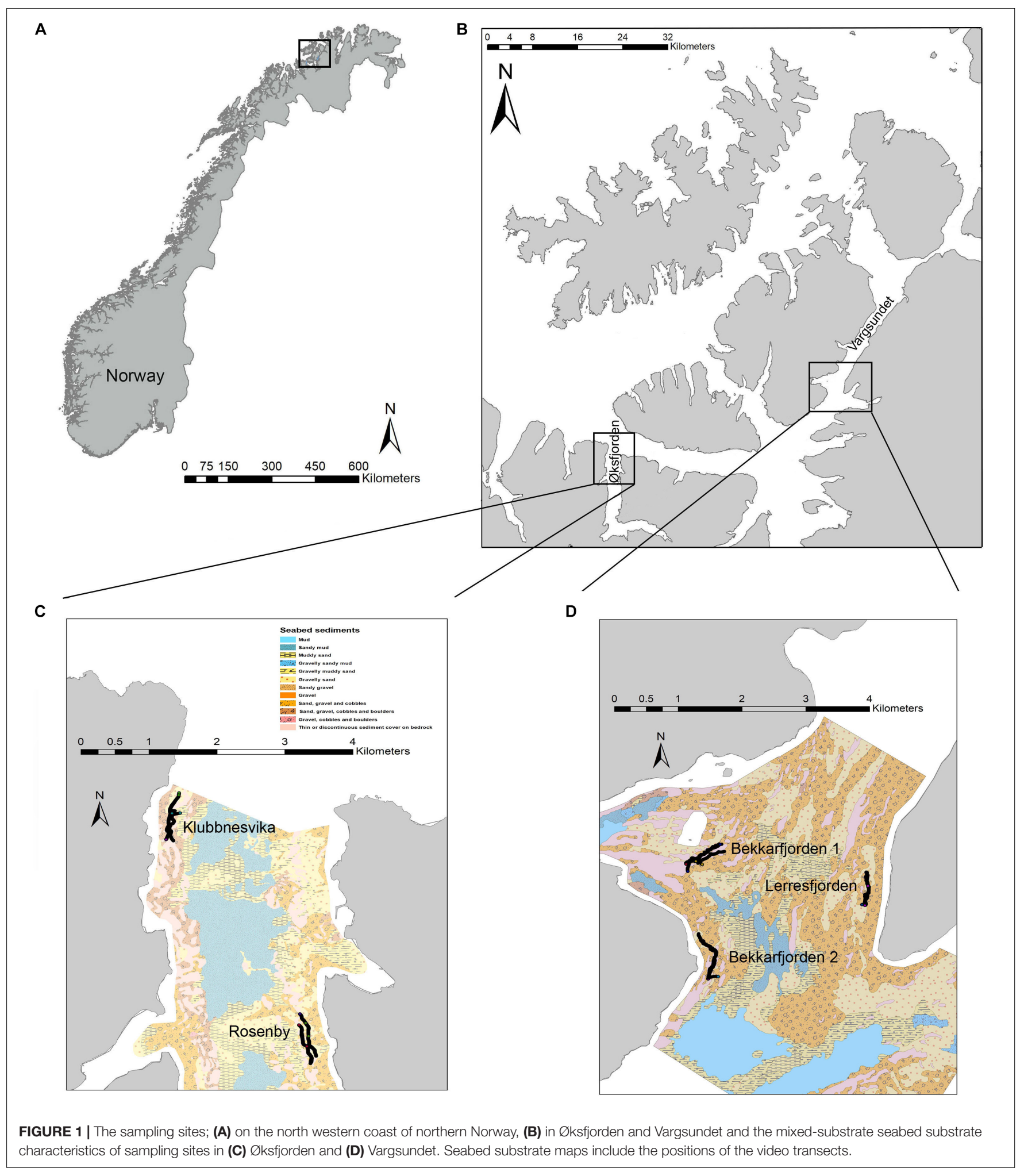

categories, such as "encrusting Polychaetes." The density of each individual taxa in each swath were quantified from video annotations by dividing abundance by the estimated swath area ( $\mathrm{m}^{-2}$ per section).

\section{Statistical Analysis}

Environmental Site Characteristics

Sequential bar plots were used to visualize the percentage coverage of each substrate type recorded along individual video 
TABLE 1 | Survey site locations and characteristics.

\begin{tabular}{|c|c|c|c|c|c|c|}
\hline Site & Fjord & Farm position & $\begin{array}{l}\text { Depth contour (m) } \\
\text { and number of } \\
\text { transects }\end{array}$ & Primary slope category & $\begin{array}{c}\text { Horizontal } \\
\text { bottom current } \\
\text { velocity }\left(\mathrm{m} \mathrm{s}^{-1}\right)\end{array}$ & $\begin{array}{l}\text { Primary substrate } \\
\text { characteristics }\end{array}$ \\
\hline Klubbnesvika & Øksfjorden & $70.26^{\circ} \mathrm{N}, 23.28^{\circ} \mathrm{E}$ & $\begin{array}{l}70(n=1) \\
100(n=2)\end{array}$ & $\begin{array}{l}\text { Steep }\left(41-70^{\circ}\right) \\
\text { Near-Vertical }\left(70-90^{\circ}\right)\end{array}$ & 0.032 & $\begin{array}{l}\text { Bedrock, Boulders, and } \\
\text { Gravelly Sand }\end{array}$ \\
\hline Rosenby & Øksfjorden & $70.22^{\circ} \mathrm{N}, 23.32^{\circ} \mathrm{E}$ & $\begin{array}{c}70(n=2) \\
100(n=2)\end{array}$ & $\begin{array}{l}\text { Steep }\left(41-70^{\circ}\right) \\
\text { Near-Vertical }\left(70-90^{\circ}\right)\end{array}$ & 0.030 & $\begin{array}{l}\text { Bedrock, Boulders, and } \\
\text { Gravelly Sand }\end{array}$ \\
\hline Bekkarfjorden 1 & Vargsundet & $70.33^{\circ} \mathrm{N}, 23.36^{\circ} \mathrm{E}$ & $\begin{array}{c}70(n=2) \\
100(n=1)\end{array}$ & $\begin{array}{l}\text { Moderate }\left(16-40^{\circ}\right) \text {, } \\
\text { Steep }\left(41-70^{\circ}\right) \text {, } \\
\text { Near-Vertical }\left(70-90^{\circ}\right)\end{array}$ & 0.025 & $\begin{array}{l}\text { Gravelly Sand, Gravel and } \\
\text { Cobbles, Bedrock and } \\
\text { Boulders }\end{array}$ \\
\hline Bekkarfjorden 2 & Vargsundet & $70.31^{\circ} \mathrm{N}, 23.36^{\circ} \mathrm{E}$ & $100(n=2)$ & $\begin{array}{l}\text { Moderate }\left(16-40^{\circ}\right) \text {, } \\
\text { Steep }\left(41-70^{\circ}\right), \\
\text { Near-Vertical }\left(70-90^{\circ}\right)\end{array}$ & 0.046 & $\begin{array}{l}\text { Gravelly Sand, Gravel and } \\
\text { Cobbles, Bedrock and } \\
\text { Boulders }\end{array}$ \\
\hline Lerresfjorden & Vargsundet & $70.32^{\circ} \mathrm{N}, 23.43^{\circ} \mathrm{E}$ & $70(n=2)$ & Flat $\left(0-15^{\circ}\right)$ & 0.042 & $\begin{array}{l}\text { Gravelly Sand, Gravel and } \\
\text { Cobbles }\end{array}$ \\
\hline
\end{tabular}

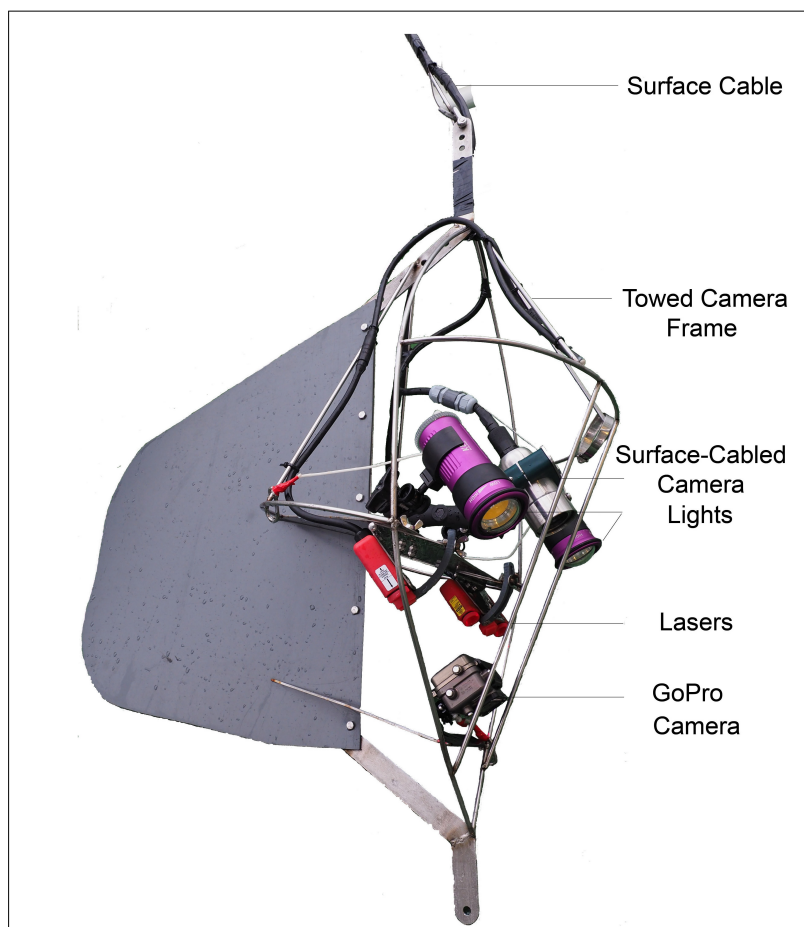

FIGURE 2 | Annotated diagram of the towed underwater camera system used to record substrate coverage and associated epifauna assemblages.

transects and were aligned with NGU substrate maps. Variation in the substrate composition between the five survey sites was visualized using a principal component analysis (PCA) based on the percentage cover of the eight substrate categories. A multivariate analysis was performed in PRIMER-E (version 7) (Clarke and Gorley, 2015) with ANOSIM to test for variation in the composition of substrate types between the survey sites. A similarity percentage analysis (SIMPER) (Clarke and Warwick, 2001) was used to determine the contribution of the different substrate types to the average similarity within and dissimilarity between sites.

\section{Biological Associations and Environmental Drivers}

The relative densities (individuals $\mathrm{m}^{-2}$ ) of the primary epifaunal taxa along transects at each of the five survey sites were calculated. Prior to the multivariate analysis, epifaunal abundances were fourth-root transformed and used to construct a Bray-Curtis similarity matrix. A SIMPER analysis was used to identify the epifauna taxa characterizing the biological assemblages at each survey site. The relative density of key sessile epifauna, identified in the SIMPER analysis, along the transects were plotted in kite graphs that were aligned with bottom substrate maps to visualize the associations between epifauna and substrate coverage. A canonical analysis of principal coordinates (CAP) was then used to visualize the influence of environmental variables and individual epifaunal taxa on the variation in epifaunal assemblage composition amongst the survey sites. A DISTance-based Linear Model (DISTLM) multiple stepwise regression analysis was used to test the influence of the environmental variables (coverage of substrate types, depth, current horizontal velocity and seabed slope) on epifaunal assemblage structure (Anderson et al., 2008).

\section{RESULTS}

\section{Substrate Composition and Hydrodynamic Characteristics}

The primary substrate at Lerresfjorden was gravel and cobbles, followed by gravelly sand (Figure 3 and Supplementary Table 3A). The topography of the site was predominantly flat, with some moderately sloped sections. At both survey sites in Bekkarfjorden, transects covered a patchy mixed/hard bottom substrate that consisted of gravel and cobbles and gravelly sand interspersed with bedrock and boulders (Figures 4A,B and Supplementary Tables 3B,C). The topography at both sites was generally steep but also highly varied, changing from flat to near-vertical in some sections. The transects conducted in Øksfjorden (Rosenby and Klubbnesvika) covered a bottom substrate dominated by bedrock and boulders with patches of gravelly sand and gravel and cobbles (Figures 5A,B and Supplementary Tables 3D,E). The substrate composition 


\section{Lerresfjorden}
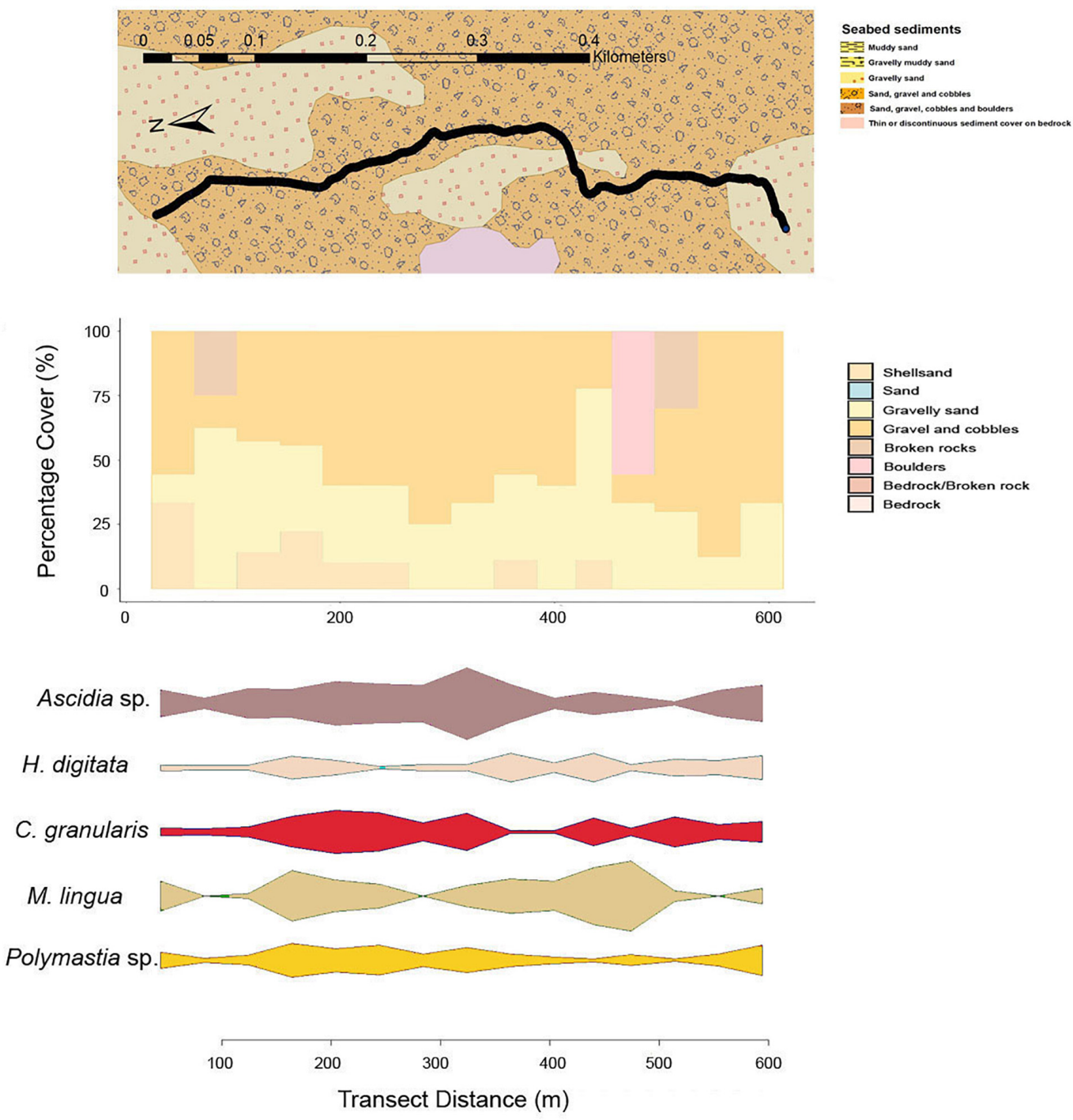

FIGURE 3 | Mixed-substrate seabed characteristics, sequential bar plots of the percentage coverage of the primary substrate types from the camera transects and densities of key epifaunal species or genus at the transect sites in Lerresfjorden.

and characteristics at the different survey sites showed some separation between the Lerresfjorden and Bekkarfjorden sites in the Principal Components Analysis (PCA) (Figure 6, vector information in Supplementary Table 4) however, overlap in the substrate composition existed between the Øksfjorden and Bekkerfjorden sites. The ANOSIM analyses detected some differentiation between the substrate composition of the five survey sites (ANOSIM, $R^{2}=0.394, p=0.001$ ). Within this, however, site characteristics at Lerresfjorden showed the greatest separation to the sites in Bekkarfjorden and Øksfjorden. A greater overlap in site characteristics was seen between both Bekkarfjorden and Øksfjorden as both contained mixed bedrock and soft substrates, steep topography and deeper water (Figure 6). Mean horizontal current flow velocity at the sites ranged between $0.02-0.05 \mathrm{~m} \mathrm{~s}^{-1}$. The fastest current velocity was observed at Bekkarfjorden $2\left(0.05 \mathrm{~m} \mathrm{~s}^{-1}\right)$ followed by Lerresfjorden $\left(0.04 \mathrm{~m} \mathrm{~s}^{-1}\right)$. Bekkerfjorden 1 and the two Øksfjorden sites experienced a mean current flow velocity of approximately $0.03 \mathrm{~m} \mathrm{~s}^{-1}$ (Table 1). Two current velocity categories $\left(0.02-0.03\right.$ and $\left.0.04-0.05 \mathrm{~m} \mathrm{~s}^{-1}\right)$ were used for further analysis (Table 2).

\section{Epifauna Assemblage Composition}

Biological coverage of the hard and mixed substrates in the survey sites were dominated by sponges (Geodia sp., Phakellia ventilabrum, Mycale lingua, Axinella infundibuliformis, Polymastia sp.). The other principal epifaunal taxa observed in the survey sites included the sponge eating asteroid Ceramaster granularis, nephtheid soft coral Duva florida, the sea anemone Hormathia digitata and the tunicate Ascidia sp. 
A
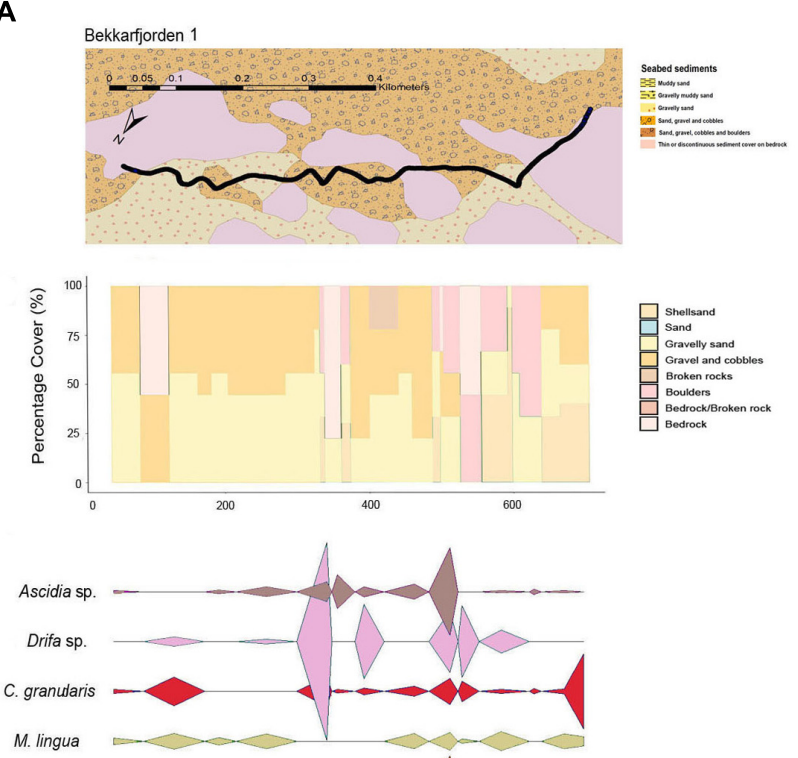

Polymastia sp.

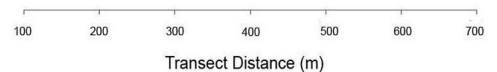

B Bekkarjorden 2
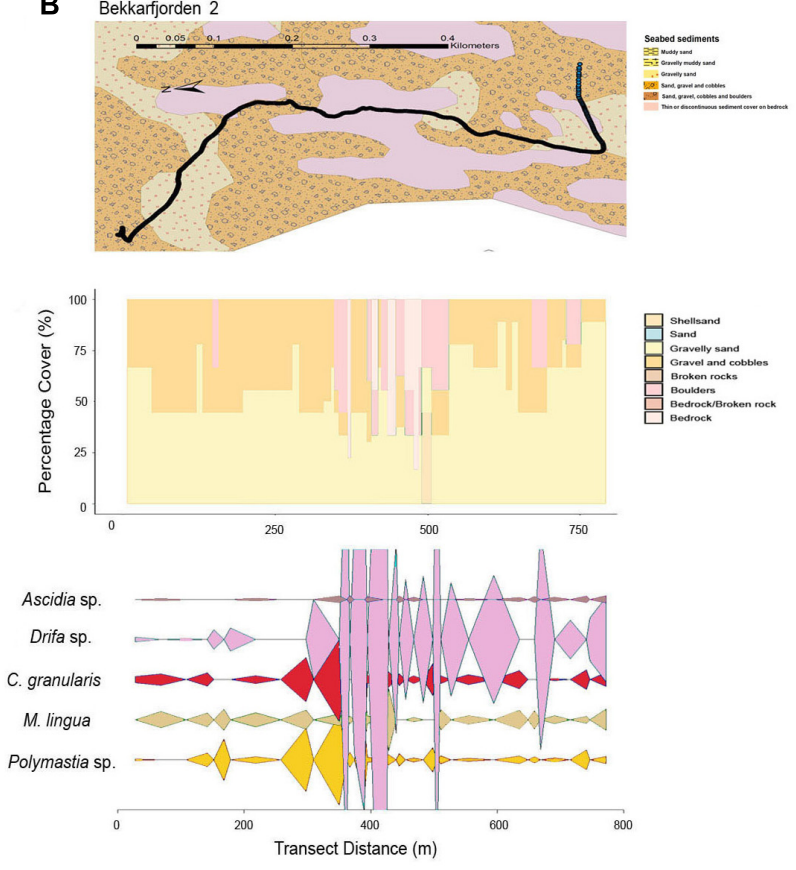

FIGURE 4 | Mixed-substrate seabed characteristics, sequential bar plots of the percentage coverage of the primary substrate types from the camera transects and densities of key epifaunal species or genus at the transect sites in (A) Bekkarfjorden 1 and (B) Bekkarfjorden 2.

A
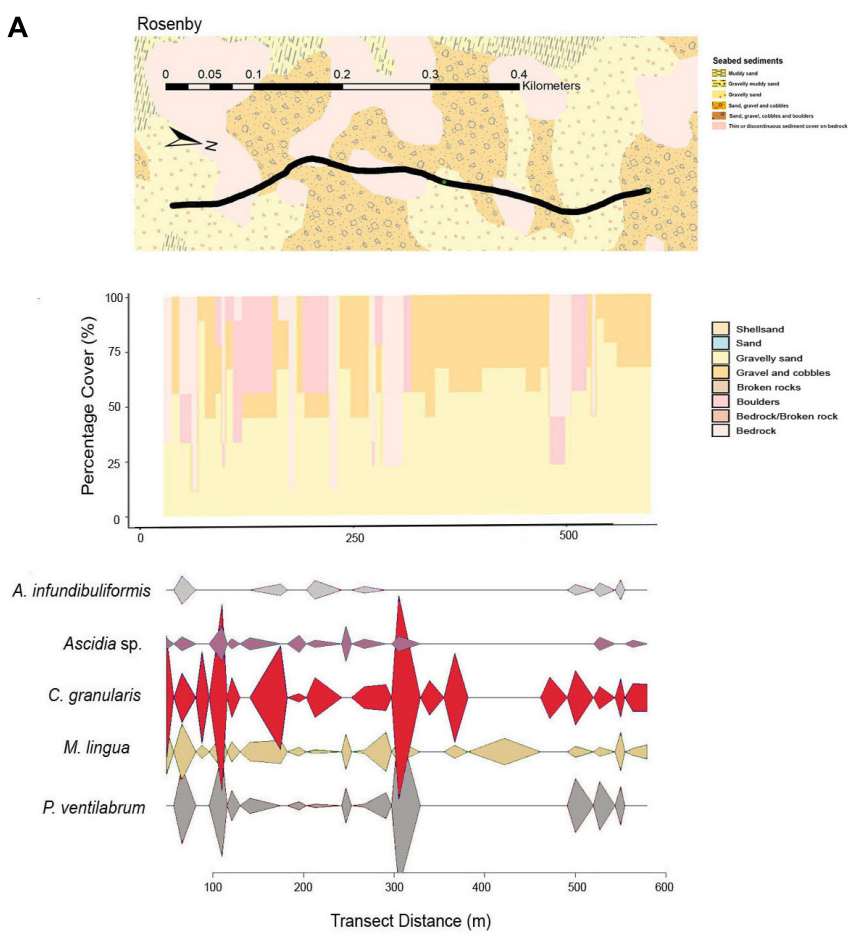

B
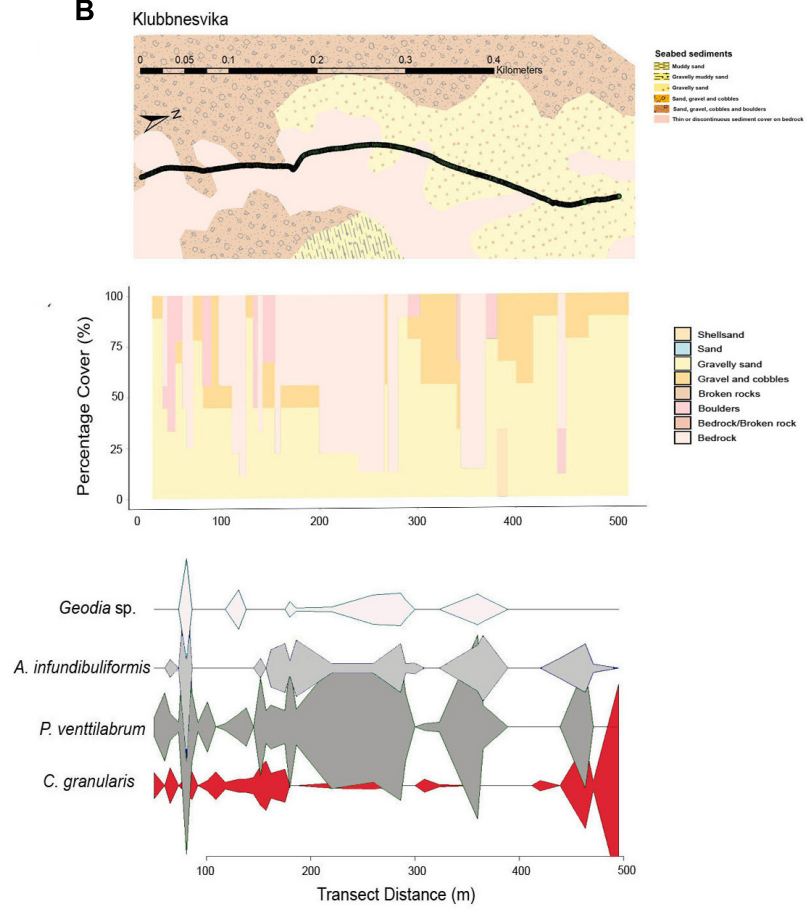

FIGURE 5 | Mixed-substrate seabed characteristics, sequential bar plots of the percentage coverage of the primary substrate types from the camera transects and densities of key epifaunal species or genus at the transect sites in (A) Rosenby and (B) Klubbnesvika. 


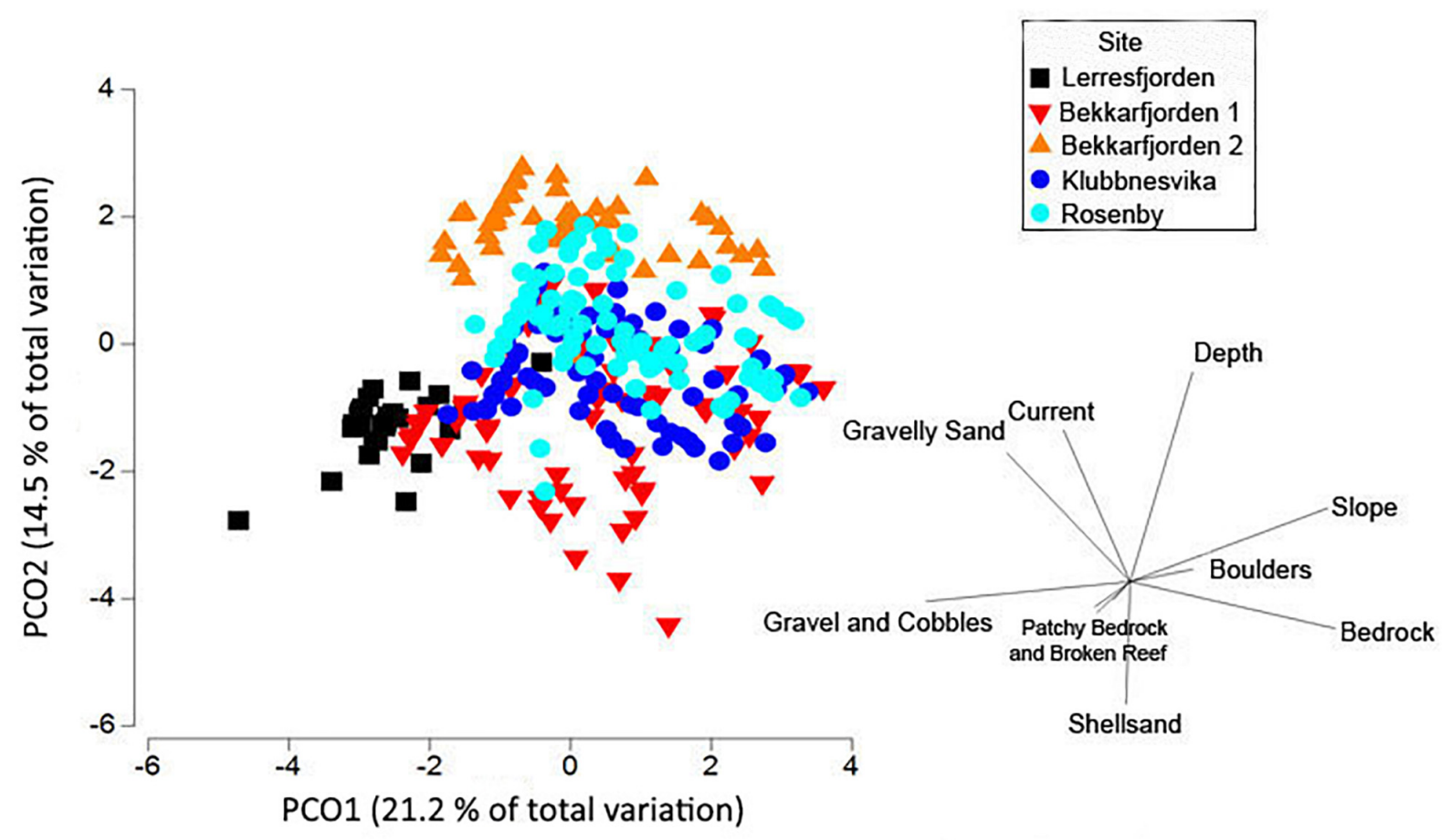

FIGURE 6 | Principal components analysis plot of the substrate type (gravelly sand, gravel and cobbles, sand, shellsand, bedrock, boulders, broken rocks and patchy bedrock and broken rocks) and other physical variables (slope, horizontal current velocity, and depth) at the five survey sites (Lerresfjorden, Bekkarfjorden 1 and 2, Rosenby, and Klubbnesvika). Environmental data was normalized and an Euclidean distance matrix applied.

TABLE 2 | Table presenting the principal epifaunal taxa characterizing seafloor sites surveyed in Finnmark, northern Norway, at specific combinations of depth contours $(\mathrm{m})$ and horizontal current velocities $\left(0.02-0.05 \mathrm{~m} \mathrm{~s}^{-1}\right)$.

\begin{tabular}{|c|c|c|c|}
\hline & \multicolumn{3}{|c|}{ Current velocity $\left(\mathrm{m} \mathrm{s}^{-1}\right)$} \\
\hline & & $0.02-0.03$ & $0.04-0.05$ \\
\hline \multirow[t]{2}{*}{ Depth (m) } & 70 & $\begin{array}{l}\text { Ascidia sp. } \\
\text { Mycale lingua } \\
\text { Phakellia ventilabrum } \\
\text { Ceramaster granularis }\end{array}$ & $\begin{array}{l}\text { Ascidia sp. } \\
\text { Polymastia sp. } \\
\text { Hormathia digitata } \\
\text { Mycale lingua } \\
\text { Ceramaster granularis }\end{array}$ \\
\hline & 100 & $\begin{array}{l}\text { Phakellia ventilabrum } \\
\text { Axinella } \\
\text { infundibuliformis } \\
\text { Ceramaster granularis }\end{array}$ & $\begin{array}{l}\text { D. florida } \\
\text { Polymastia sp. } \\
\text { Mycale lingua } \\
\text { Ceramaster granularis }\end{array}$ \\
\hline
\end{tabular}

(Figure 7 and Supplementary Figure 1). The composition of epifaunal assemblages showed a clear separation in the CAP analysis between the survey sites in Øksfjorden (Rosenby and Klubbnesvika), Lerresfjorden and Bekkarfjorden. Depth, current velocity, the slope of the seafloor and the coverage of bedrock and gravel and cobbles were major drivers structuring the epifaunal community composition (Figure 8). The marginal tests from the DISTLM multiple regression model show that these five environmental variables had significant effects $(p=0.001$ for all variables) on epifaunal assemblage structure. In addition, the coverage of gravelly sand and shellsand had a lesser but still significant impact on community composition $(p=0.007$ and $p=0.03$ ). Results of the DISTLM multiple regression model are presented in Supplementary Table 5. The principal epifaunal species found within two horizontal current velocity categories (0.02-0.03 and $\left.0.04-0.05 \mathrm{~m} \mathrm{~s}^{-1}\right)$ and depth contours 70 and $100 \mathrm{~m}$ (the two site characteristics found to have the strongest effect on epifaunal community composition), were extracted with a SIMPER analysis and are displayed in Table 2. P. ventilabrum was characteristic of sites with lower current velocity (0.02$0.03 \mathrm{~m} \mathrm{~s}^{-1}$ ) at both 70 and $100 \mathrm{~m}$ depth contours, while the sponge $A$. infundibuliformis only characterized sites with $0.02-$ $0.03 \mathrm{~m} \mathrm{~s}^{-1}$ current velocity at $100 \mathrm{~m}$ depth. Ascidia sp. was dominant in communities at both current speed categories but only in $70 \mathrm{~m}$ water depth. Polymastia sp. was key to epifaunal assemblages in sites with faster current velocity at both depth contours. D. florida was identified as a dominant taxon only in sites at $100 \mathrm{~m}$ in $0.04-0.05 \mathrm{~m} \mathrm{~s}^{-1}$ current velocity and higher densities of $H$. digitata were present in sites at $70 \mathrm{~m}$ depth with $0.04-0.05 \mathrm{~m} \mathrm{~s}^{-1}$ horizontal current velocity.

At Lerresfjorden, 21 individual taxa were observed with a Shannon-Wiener index (base 2) of $3.19( \pm 0.4)$ (mean \pm st.dev) (Table 3). At this site the mean ( \pm S.E.) density of all epifaunal taxa was $1.03( \pm 0.11)$ and $0.90( \pm 0.13)$ individuals $\mathrm{m}^{-2}$. The tunicate Ascidia sp. dominated the epifaunal community with an average density of 0.22 individuals $\mathrm{m}^{-2}$ recorded in both 

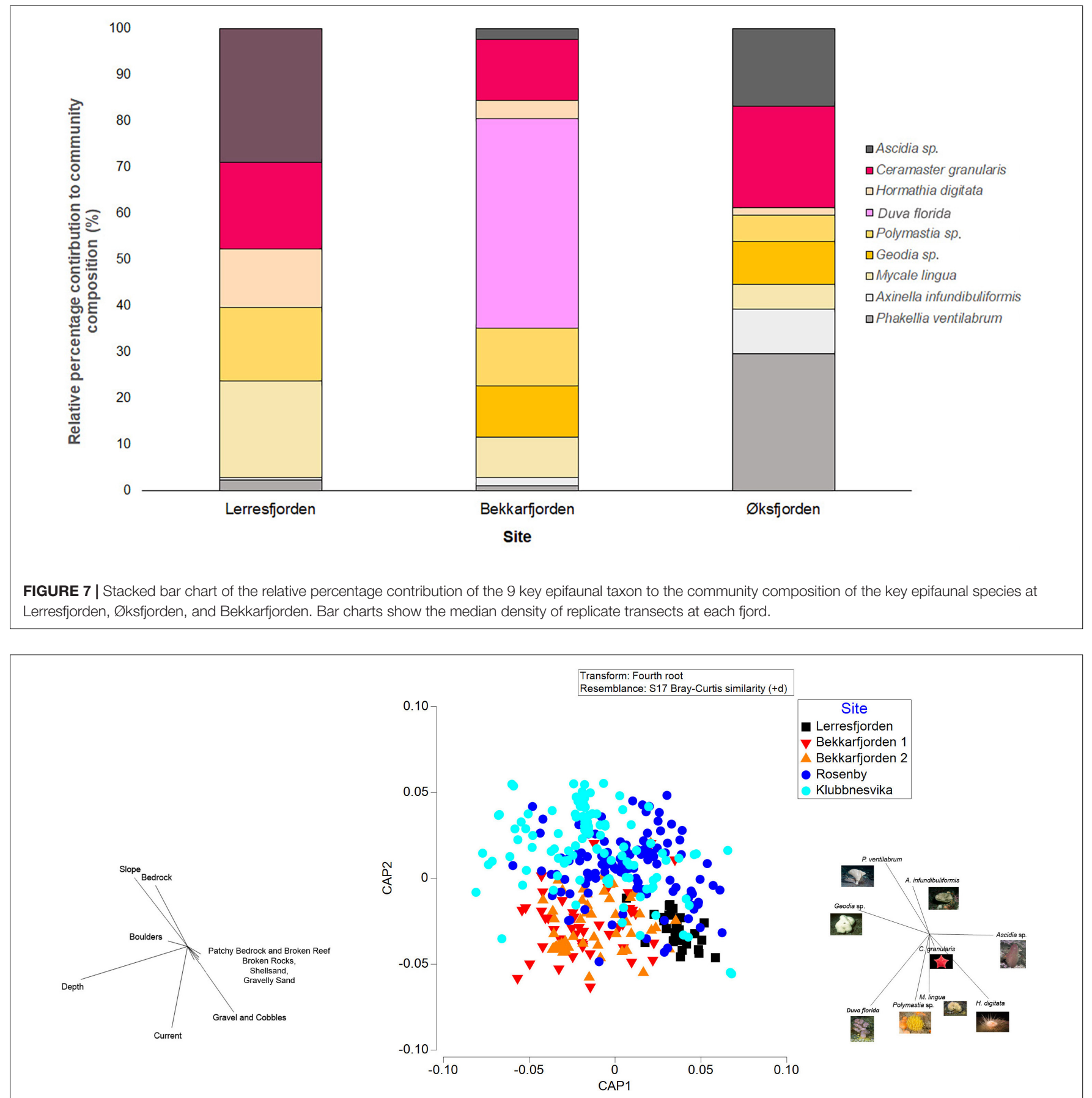

FIGURE 8 | Canonical analysis of principal coordinates, based on Bray-Curtis dissimilarity, of the composition of epifaunal taxa at the survey sites (Lerresfjorden, Bekkarfjorden 1 and 2, Rosenby, and Klubbnesvika). Vectors overlays to the left represent the Spearman rank correlations between epifaunal community structure and substrate and other environmental characteristics. The vector overlay to the right shows the 9 epifauna taxa with the highest Spearman rank correlations with the canonical axes.

transects (Figure 7). Ascidia sp. represented $19.8 \%$ of the average abundance of the benthic community (Supplementary Table 6A). Other principal components of the epifaunal assemblages included the sponge $M$. lingua, cushion star C. granularis, the sponge Polymastia sp. and the sea-anemone $H$. digitata. Together these five taxa represented $78.3 \%$ of the epifaunal assemblage coverage at Lerresfjorden. M. lingua was recorded at a mean $( \pm \mathrm{SE})$ density of $0.20 \pm 0.04$ and $0.13 \pm 0.03$ individuals $\mathrm{m}^{-2}$ and C. granularis at $0.16 \pm 0.03$ and $0.13 \pm 0.04$ individuals $\mathrm{m}^{-2}$ in replicate transects. Polymastia sp. and $H$. digitata reached a mean density of $0.12( \pm 0.02)$ and $0.10( \pm 0.01)$ individuals $\mathrm{m}^{-2}$ in both replicate transects, 
TABLE 3 | Epifaunal taxa observed in towed camera transects at each study area.

\begin{tabular}{|c|c|c|}
\hline Phylum & Taxa & Sites \\
\hline \multirow[t]{8}{*}{ Porifera } & Mycale lingua & $\begin{array}{l}\text { Lerresfjorden, } \\
\text { Bekkarjorden, Øksfjorden }\end{array}$ \\
\hline & $\begin{array}{l}\text { Axinella } \\
\text { infundibuliformis }\end{array}$ & $\begin{array}{l}\text { Lerresfjorden, } \\
\text { Bekkarfjorden, Øksfjorden }\end{array}$ \\
\hline & Polymastia sp. & $\begin{array}{l}\text { Lerresfjorden, } \\
\text { Bekkarfjorden, Øksfjorden }\end{array}$ \\
\hline & $\begin{array}{l}\text { Craniella } \\
\text { zetlandica/Tethya sp. }\end{array}$ & $\begin{array}{l}\text { Lerresfjorden, } \\
\text { Bekkarfjorden, Øksfjorden }\end{array}$ \\
\hline & Myxilla sp. & Bekkarfjorden, Øksfjorden \\
\hline & Phakellia ventilabrum & $\begin{array}{l}\text { Lerresfjorden, } \\
\text { Bekkarjorden, Øksfjorden }\end{array}$ \\
\hline & Isodictya palmate & Bekkarfjorden, Øksfjorden \\
\hline & Geodia sp. & Bekkarfjorden, Øksfjorden \\
\hline \multirow[t]{5}{*}{ Cnidaria } & Hormathia digitata & $\begin{array}{l}\text { Lerresfjorden, } \\
\text { Bekkarfjorden, Øksfjorden }\end{array}$ \\
\hline & Cerianthus Iloydii & $\begin{array}{l}\text { Lerresfjorden, } \\
\text { Bekkarjorden, Øksfjorden }\end{array}$ \\
\hline & Duva florida & $\begin{array}{l}\text { Lerresfjorden, } \\
\text { Bekkarfjorden, Øksfjorden }\end{array}$ \\
\hline & Urticina eques & $\varnothing \mathrm{ksfjorden}$ \\
\hline & Primnoa resedaeformis & $\varnothing$ ksfjorden \\
\hline \multirow[t]{12}{*}{ Echinodermata } & Ceramaster granularis & $\begin{array}{l}\text { Lerresfjorden, } \\
\text { Bekkarfjorden, Øksfjorden }\end{array}$ \\
\hline & Asterias rubens & $\begin{array}{l}\text { Lerresfjorden, } \\
\text { Bekkarfjorden, Øksfjorden }\end{array}$ \\
\hline & Henricia sp. & $\begin{array}{l}\text { Lerresfjorden, } \\
\text { Bekkarfjorden, Øksfjorden }\end{array}$ \\
\hline & Hippasteria phrygiana & $\begin{array}{l}\text { Lerresfjorden, } \\
\text { Bekkarfjorden, Øksfjorden }\end{array}$ \\
\hline & $\begin{array}{l}\text { Gorgonocephalus } \\
\text { lamarckii }\end{array}$ & Bekkarfjorden \\
\hline & Stichopus tremulus & Lerresfjorden, Øksfjorden \\
\hline & Cucumaria frondosa & Øksfjorden \\
\hline & Solaster endeca & $\begin{array}{l}\text { Lerresfjorden, } \\
\text { Bekkarfjorden, Øksfjorden }\end{array}$ \\
\hline & Stichastrella rosea & Lerresfjorden, Øksfjorden \\
\hline & Echinus esculentus & $\begin{array}{l}\text { Lerresfjorden, } \\
\text { Bekkarfjorden }\end{array}$ \\
\hline & Antedon sp. & Øksfjorden \\
\hline & Ophiura sp. & Øksfjorden \\
\hline \multirow[t]{2}{*}{ Gastropoda } & Neptunea despecta & $\begin{array}{l}\text { Lerresfjorden, } \\
\text { Bekkarfjorden, Øksfjorden }\end{array}$ \\
\hline & Buccinum undatum & Lerresfjorden, Øksfjorden \\
\hline Arthropoda & Munida sp. & Bekkarfjorden, Øksfjorden \\
\hline \multirow[t]{3}{*}{ Bryozoa } & Omalosecosa ramulosa & $\begin{array}{l}\text { Lerresfjorden, } \\
\text { Bekkarfjorden, Øksfjorden }\end{array}$ \\
\hline & Securiflustra spp & $\begin{array}{l}\text { Lerresfjorden, } \\
\text { Bekkarfjorden, Øksfjorden }\end{array}$ \\
\hline & Porella compressa & Bekkarfjorden, Øksfjorden \\
\hline Chordata & Ascidia sp. & $\begin{array}{l}\text { Lerresfjorden, } \\
\text { Bekkarfjorden, Øksfjorden }\end{array}$ \\
\hline
\end{tabular}

respectively. Other common taxa at Lerresfjorden included the bryozoan Omalosecosa ramulosa, the sea stars Hippasteria phrygiana, Henricia sp., and Stichastrella rosea, the sea snail Neptunea despecta and the sponge P. ventilabrum (Table 3 and
Figure 7). The relative densities of the five most common taxa (Ascidia sp., M. lingua, C. granularis, $H$. digitate and Polymastia sp.) were relatively evenly distributed across the substrate at Lerresfjorden (Figure 3). The CAP ordination plot shows the particular importance of $H$. digitata, C. granularis and Ascidia sp. taxa in the community composition at Lerresfjorden (Figure 8). A list of epifauna taxa found at the study sites is provided in Table 3.

Twenty four individual epifaunal taxa were identified at the Bekkarfjorden survey sites with a Shannon-Wiener index (base 2 ) of 2.91 (Table 3$)$. The mean ( \pm S.E.) densities of epifaunal assemblages were $0.71 \pm 0.19$ individuals $\mathrm{m}^{-2}$ at Bekkarfjorden survey site 1 and $1.54 \pm 0.29$ individuals $\mathrm{m}^{-2}$ at survey site 2. The sponges Polymastia sp., M. lingua and the cushion star C. granularis were primary taxa in the epifaunal composition at Bekkarfjorden. However here the soft coral of the genus D. florida dominated the epifaunal community, particularly at Bekkarfjorden 2 (Figure 7). Together these four taxa represented 62.7 and $75.7 \%$ of the epifaunal assemblages, respectively, at the two Bekkarfjorden sites (Supplementary Tables 6B,C). D. florida was recorded at densities $0.22( \pm 0.08)$ and $0.79( \pm 0.24)$ individuals $\mathrm{m}^{-2}$ at site 1 and 2, respectively. D. florida was of particularly high density $1.14( \pm 0.4)$ individuals $\mathrm{m}^{-2}$ in one of the transect recorded at Bekkarfjorden site 2 at $100 \mathrm{~m}$ water depth. Polymastia sp. was recorded at densities of $0.08( \pm 0.02)$ and $0.11( \pm 0.03)$ individuals $\mathrm{m}^{-2}, C$. granularis at densities of $0.07( \pm 0.03)$ and $0.11( \pm 0.03)$ individuals $\mathrm{m}^{-2}$ and the sponge $M$. lingua with a mean density $( \pm$ S.E) of $0.05( \pm 0.01)$ and 0.08 $( \pm 0.02)$ individuals $\mathrm{m}^{-2}$. Sponges of the genus Geodia, golf ball sponges of the genus Craniella and Tethya, Henricia sp. and Ascidia sp. were also frequently encountered in some parts of the transects in both Bekkarfjorden sites. In addition, $P$. ventilabrum and A. rubens were common at Bekkarfjorden 2 (Figure 7). The density of aggregations of Polymastia sp., C. granularis and especially $D$. florida., were closely linked to the distribution of bedrock where the highest densities were recorded. The distribution of epifauna was therefore patchy in correspondence with the characteristics of substrate at the Bekkarfjorden surveys sites, which alternate between exposed bedrock on gravelly sand, bedrock and gravel and cobbles (Figures 4A,B). The CAP ordination plot highlights that D. florida, Polymastia sp. and $M$. lingua are highly associated with the Bekkarfjorden sites (Figure 8).

At Øksfjorden, 30 individual epifaunal taxa were recorded with a Shannon-Wiener index (base 2) of 3.11 (Table 3). At Rosenby, Øksfjorden, the coverage of epifaunal communities was at a mean density of $0.70( \pm 0.06)$ individuals $\mathrm{m}^{-2}$ and was primarily characterized by a high density of the sponge $P$. ventilabrum $\left(0.19 \pm 0.02\right.$ individuals $\left.\mathrm{m}^{-2}\right)$. High densities $\left(0.11 \pm 0.01\right.$ individuals $\left.\mathrm{m}^{-2}\right)$ of $C$. granularis were also observed in association with aggregations of sponges as were Ascidia sp. $\left(0.15 \pm 0.2\right.$ individuals $\left.\mathrm{m}^{-2}\right)$. The sponge $M$. lingua was also dominant at Rosenby, occurring at an average density of $0.06 \pm 0.01$ individuals $\mathrm{m}^{-2}$ (Figure 7). P. ventilabrum, C. granularis, Ascidia sp. and M. lingua contributed to $78.98 \%$ of the epifaunal assemblages at Rosenby (Supplementary Table 6D). At Klubbnesvika, epifaunal communities were at a 
density of $0.88( \pm 0.08)$ individuals $\mathrm{m}^{-2}$. As found at Rosenby, the taxa that occurred at the highest density was $P$. ventilabrum $\left(0.39 \pm 0.04\right.$ individuals $\left.\mathrm{m}^{-2}\right)$ and $C$. granularis $(0.11 \pm 0.02$ individuals $\mathrm{m}^{-2}$ ). Epifaunal assemblages at Klubbnesvika were also characterized by the sponge $A$. infundibuliformis $(0.10 \pm 0.02$ individuals $\mathrm{m}^{-2}$ ) and in addition sponges of the genus Geodia $\left(0.12 \pm 0.04\right.$ individuals $\left.\mathrm{m}^{-2}\right)$. The SIMPER analysis showed that $P$. ventilabrum and C. granularis represented $71.37 \%$ of the taxa observed at Klubbnesvika (Supplementary Table 6E). Similar to Bekkarfjorden, the distributions of these taxa were closely associated with the distribution of bedrock substrate and thus showed a patchy distribution (Figures $\mathbf{5 A}, \mathbf{B}$ ). The CAP ordination plot clearly displays that $P$. ventilabrum, A. infundibuliformis, and Geodia sp. are strongly associated with both Øksfjorden sites and Ascidia sp. also plays an important role in the community composition (Figure 8).

\section{DISCUSSION}

\section{Key Findings}

The results from this study directly address the need for knowledge on the diversity and spatial distribution of hard and mixed substrate habitats and associated epifaunal taxa in northern Norwegian fjords. The diversity and distribution of sessile epibenthic communities at five sites with hard and mixed seafloor substrates types that are representative of seafloors in coastal northern Norway are described. Epifaunal communities were dominated by five sponge taxa (P. ventilabrum, A. infundibuliformis, Polymastia sp., M. lingua, and Geodia sp.). P. ventilabrum and $A$. infundibuliformis were primarily observed at sites with hard substrate and relatively slower horizontal current velocity $\left(0.02-0.03 \mathrm{~m} \mathrm{~s}^{-1}\right)$. Alternatively, sponges of the genus Polymastia were mainly in mixed substrate sites with relatively faster current velocity (0.04-0.05 $\left.\mathrm{m} \mathrm{s}^{-1}\right)$. The cushion star (C. granularis) was a principal component of epifaunal assemblages at all survey sites. In addition, the soft coral (D. florida) dominated communities associated with patchy hard substrates in water depths of approximately $100 \mathrm{~m}$ with fast current velocity. The sea anemone $H$. digitata was only observed in shallower waters $(57-77 \mathrm{~m})$ at Lerresfjorden which was characterized by flat mixed substrate and a fast current velocity. The tunicate Ascidia sp. was common at all sites but most common at shallower water depths of $70 \mathrm{~m}$. Environmental drivers significant to the composition and distribution of epifaunal assemblages in the area were identified as; current velocity, water depth, seafloor slope, and the coverage of bedrock substrates.

\section{Low-Cost Survey Technique for Quantifying Coastal Epifaunal Assemblages}

Approaches to quantify epifaunal assemblages include dredges, trawls and towed benthic sledges or drop-down camera systems. These sampling techniques, however, are generally unsuitable for use on rugged or steep terrain and for sampling communities containing vulnerable and valuable taxa (Przeslawski et al., 2018). The hard and mixed substrate habitats surveyed in this study were beyond normal diving depths, notoriously patchy and situated on complex 3-dimensional bathymetry. The novel, non-destructive, towed camera approach taken here to survey these habitats, has proved to be an effective method for describing and quantifying the associated epibenthic communities. In particular, the ability of this system to efficiently sample an area in the range of ten's to thousand's $\mathrm{m}^{-2}$ (dependent on the study objectives and distributions of the organisms of interest) coupled with the ability to retrospectively scale the images and thereby quantify the fauna is key to obtaining detailed and spatially intensive ecological information. It represents a low-cost technique for describing epifaunal assemblages that is conducive to routine monitoring in response to anthropogenic disturbances. With the current rapid evolution of supervised machine learning and image recognition software (Piechaud et al., 2019), the post-processing phase of this method will very likely soon be automated and streamlined.

\section{Sponge Ground Communities and Substrate Association}

Local aggregations of sponges (also known as sponge grounds) generally form on hard substrates suitable for attachment and where currents enhance food supply (Hogg et al., 2010; Maldonado et al., 2017). On the Norwegian continental shelf, benthic communities on hard and mixed substrates are dominated by deep-water sponge grounds and cold-water coral ecosystems (Tjensvoll et al., 2013; Buhl-Mortensen et al., 2017). Both cold-water sponge and coral communities are known to create hotspots for marine biodiversity (Jonsson et al., 2004; Schöttner et al., 2013; Howell et al., 2016) by providing structurally complex habitats for associated epifaunal and infaunal communities (Ribeiro et al., 2003; Knudby et al., 2013) and nursery grounds for commercial fish stocks (Baillon et al., 2012; Miller et al., 2012). For example, in this study, Norway redfish (Sebastes viviparus) were observed in close association with aggregations of the soft coral $D$. florida. Sponge grounds filter large volumes of water and therefore play a significant role in carbon processing on the seafloor (Kutti et al., 2013; Cathalot et al., 2015). The filtering capabilities of sponges, however, also make them susceptible to clogging from sediments and organic material in the water column (Kutti et al., 2015). Sponges, as well as corals, have been shown to recover slowly from impacts due to their slow growth, long-life span and infrequent reproduction (Fosså et al., 2002; ICES, 2009).

In recognition of the important ecological role of these sponge communities and the risks posed by anthropogenic impacts, extensive sponge grounds known as "ostur" habitats on the continental shelf of the northeastern Atlantic have been classified as vulnerable marine ecosystems (Howell et al., 2016; BuhlMortensen et al., 2019). Ostur sponge grounds are dominated by sponges of the genus Geodia, Stryphnus, Stelletta, Thena, and Phakellia (Hogg et al., 2010; Kutti et al., 2013; Tjensvoll et al., 2013; Maldonado et al., 2017) and are defined as areas where sponges occur at densities between 0.5 and 1 individuals per $\mathrm{m}^{-2}$ in video surveys (Hogg et al., 2010; Kutti et al., 
2013). The sponges Geodia barretti (and other sponges of the genus Geodia), P. ventilabrum and $M$. lingua were common in ostur sponge habitats in the Traenadypet coral MPA, on the northern Norwegian continental shelf (Kutti et al., 2013) and in Korsfjorden, western Norway (Schöttner et al., 2013).

The average densities ( \pm S.E.) of G. barretti (0.19 individuals $\left.\mathrm{m}^{-2} \pm 0.02\right)$, $P$. ventilabrum $\left(0.13\right.$ individuals $\left.\mathrm{m}^{-2} \pm 0.02\right)$ and $M$. lingua (0.08 individuals $\left.\mathrm{m}^{-2} \pm 0.02\right)$ at Traenadypet were comparable to the densities of these same taxa in the surveyed coastal areas of Vargsundet and Øksfjorden. Sponge aggregations at the Øksfjorden survey sites, particularly Klubbnesvika, can be considered as ostur sponge beds. The mean density of sponges recorded in Klubbnesvika transects were between 0.58 and 0.73 individuals $\mathrm{m}^{-2}$ and between 0.1 and 0.57 individuals $\mathrm{m}^{-2}$ at Ronsenby. Sponge densities were lower in transects in Lerresfjorden at 0.30 and 0.34 individuals $\mathrm{m}^{-2}$ and at both Bekkarfjorden sites (0.24-0.59 individuals $\mathrm{m}^{-2}$ ). The cup or lamellate-shaped sponges $P$. ventilabrum and A. infundibuliformis have been observed to dominate sponge communities on wave-exposed circalittoral rock habitat (Connor et al., 2004). Both these species are also known to be associated with the sandy-gravel and cobbles on the continental shelf in eastern part of Tromsøflaket (Buhl-Mortensen et al., 2012). The densities of these two species were highest in transects in Klubbnesvika and Rosenby where their distributions were closely associated with the presence of bedrock and current velocities in the range of $\left(0.02-0.03 \mathrm{~m} \mathrm{~s}^{-1}\right)$.

Sponges of the genus Polymastia are common in the Nordic sea and have been described as a sub-dominant group in epifaunal communities on hard-bottom substrates in Norwegian fjords (Plotkin et al., 2018). This genus was associated with sandy gravel with cobbles and boulder on morainic ridges on the eastern Tromsøflaket (Buhl-Mortensen et al., 2012). In this study, Polymastia sp. was a dominant sponge in all survey areas, but particularly characterized environments with faster current velocities (0.04-0.05 $\left.\mathrm{m} \mathrm{s}^{-1}\right)$. Geodia sponges are known to attach to stable substrates in high energy environments but also use small stones (i.e., gravel) to achieve negative buoyancy in low energy environments (Tjensvoll et al., 2013). Also in this study, sponges of the genus Geodia were common in varied current flow environments at both the mixed substrate sites in Bekkerfjorden and on bedrock outcrops at the Øksfjorden sites. Sponge aggregations in all survey sites were colonized by the cushion star (C. grannularis). This species is known from stable isotope analysis and stomach content analysis to primarily feed on sponges (Gale et al., 2013) and the species' distribution can therefore be easily explained by the presence of sponges.

Limited information exists on the distribution of nephtheid soft corals in Norway but it is thought that multiple species exists, including D. florida and D. glomerata. Aggregations of nephtheid soft corals have been described on the continental slope off Vesterålen at depths of 1000-1500 m (Buhl-Mortensen et al., 2012) and also recently in Hordaland, south western Norway, down to depths of $95 \mathrm{~m}$ (Husa et al., 2019). The dominance of D. florida particularly at Bekkarfjorden 2 indicates that the genus is specialized to colonize highly mixed hard substrates and to thrive in faster current velocities (in our study, $0.05 \mathrm{~m} \mathrm{~s}^{-1}$ ). The boreal sea anemone $(H$. digitata) is a common species in depths between 10-1000 m in Arctic and sub-Arctic waters (RiemannZürneck, 1994; Sirenko et al., 2004) and has been found to be associated with areas of silt to very fine sand (Callaway et al., 2002). In this study, $H$. digitata was observed to be particularly common on the flat gravel and gravelly sand substrates at Lerresfjorden and often in association with the marine gastropod N. despecta.

There is increasing recognition of the importance of ecosystem-based management approaches which focus on the combined protection of ecosystem structure, function and processes (Kershner et al., 2011; Bourdaud et al., 2016). Information on the spatial patterns of substrates and associated biological assemblages, and their relationships with environmental drivers, can form the basis to develop an ecosystem-based management strategy using tools such as predictive spatial distribution models (Guisan and Zimmermann, 2000; Guisan and Thuiller, 2005). Predictive spatial distribution models (also known as habitat suitability models) use the known relationships between taxa distribution and abiotic variables to predict the distribution of taxa when only the geographically referenced environmental conditions are available (Elith and Leathwick, 2009). The predictive spatial distribution modeling approach has been used to successful predict the large-scale occurrence of VMEs containing deep-sea sponges in the North Atlantic, Norwegian and Barents Sea (Knudby et al., 2013; Howell et al., 2016; Ross et al., 2019). This study has identified abiotic factors that influence the spatial diversity and distribution of epifauna in a poorly studied coastal area in northern Norway. Local hydrodynamic regimes, depth, topographical slope and the presence of hard bedrock substrates were identified as main drivers in the structuring of epibenthic communities. Horizontal current velocity and depth, however, showed to be the most important structuring variables. Current flow in particular has previously been considered to play an important role in the distribution of ostur sponge habitats (Klitgaard and Tendal, 2001). The environmental variables, temperature, salinity and silicate concentrations were not measured here, but are known to be important in the broad-scale distribution of sponge grounds in deep waters (Howell et al., 2016). However, these variables are not expected to vary greatly between the study sites given their proximity to a shared and relatively well flushed water body. This information on the relationships between epifaunal distribution and abiotic variables can be used as a basis for the development of predictive spatial distribution models for the wider northern Norwegian coastal area, thus contributing to better ecosystem-based management.

\section{Summary and Conclusion}

Despite the recognition of the importance of hard substrate epifaunal communities and growing coastal anthropogenic activities, these assemblages remain poorly mapped in Norwegian fjords and the North Atlantic. This study utilized a simple, low-cost but innovative method to describe the abundance, composition, distribution and substrate association of benthic epifaunal communities on hard and mixed substrates in northern Norwegian coastal waters. The study area in coastal 
northern Norway contains rich sponge beds and associated epifaunal communities. These assemblages are likely to be of high ecological importance and vulnerable to anthropogenic disturbance as are deep-water sponge beds and cold-water coral reefs. Considering the growing pressures on northern ecosystems by industrial activity and climate change, this work highlights the need to gain a better understanding of the associated impacts on epibenthic assemblages in Arctic and sub-Arctic coastal waters. Furthermore, the here given insights on environmental drivers of distribution and composition of epibenthic assemblages provide a basis for predictive spatial distribution models to be used in ecosystem-based management approaches for the rapidly developing Arctic and sub-Arctic coastal regions.

\section{DATA AVAILABILITY STATEMENT}

The original contributions presented in the study are included in the article/supplementary material, further inquiries can be directed to the corresponding author.

\section{AUTHOR CONTRIBUTIONS}

$\mathrm{NK}$ and AH planned and led the field data collection, while LP planned and led the marine geological surveys. KD analyzed the data and led the writing of the manuscript. All authors contributed to manuscript planning and writing. Substrate maps were created by LP and edited by KD.

\section{FUNDING}

The study was supported by a project grant from the Norwegian Research Council (Project \#267829).

\section{ACKNOWLEDGMENTS}

We are grateful to Raymond Bannister for his role in project leadership and work in the field and Erika Gonzales Casal for

\section{REFERENCES}

Aanesen, M., Falk-Andersson, J., Vondolia, G. K., Borch, T., Navrud, S., and Tinch, D. (2018). Valuing coastal recreation and the visual intrusion from commercial activities in Arctic Norway. Ocean Coast. Manage. 153, 157-167. doi: 10.1016/j.ocecoaman.2017.12.017

Albretsen, J., Sperrevik, A. K., Staalstrøm, A., Sandvik, A. D., Vikebø, F., and Asplin, L. (2011). Norkyst-800 Report No. 1: User Manual and Technical Descriptions, Fisken og Havet. Bergen: Havforskningsinstituttet.

Anderson, M., Gorley, R. N., and Clarke, R. K. (2008). Permanova+ for Primer: Guide to Software and Statistical Methods. Plymouth: Primer-E Limited.

Anon (2014-2015). Forutsigbar og miljømessig borekraftig vekst i norsk lakse- og ørretoppdrett (in Norwegian), St.prp. nr. 16. Oslo: Ministry of Trade, Industry and Fisheries.

Baillon, S., Hamel, J. F., Wareham, V. E., and Mercier, A. (2012). Deep coldwater corals as nurseries for fish larvae. Front. Ecol. Environ. 10, 351-356. doi: $10.1890 / 120022$

Bannister, R. J., Johnsen, I. A., Hansen, P. K., Kutti, T., and Asplin, L. (2016). Near-and far-field dispersal modelling of organic waste from Atlantic salmon video annotating. We also thank Nils Fanghol for skippering the RV Fangst upon which fieldwork was conducted, Lars Aspen for modeling the current velocity data for the manuscript results and Pia Kupka Hansen for assistance in the field. A special thank you goes to Olivier Laroche for performing the DNA sequencing and Chris Yesson (ZSL) for the mitogenomic information for Nephtheid soft coral and finally the two reviewers who provided constructive comments to improve the manuscript.

\section{SUPPLEMENTARY MATERIAL}

The Supplementary Material for this article can be found online at: https://www.frontiersin.org/articles/10.3389/fmars. 2020.568802/full\#supplementary-material

Supplementary Figure 1 | Images of the nine most abundantly dominant epifaunal species observed in towed underwater camera surveys in coastal north western Norway.

Supplementary Table 1 | Details of survey transects recorded at survey sites in Finnmark, northern Norway as surveyed by the towed underwater camera system.

Supplementary Table 2 | List of seafloor substrate categories observed in towed video camera transects in Finnmark, northern Norway. Details included on classification based on the Norwegian Geological Survey standard based on the classification by Folk, 1954.

Supplementary Table 3 | Results of the SIMPER analysis showing the cumulative contribution of individual taxa to the composition of epifaunal communities' composition at each survey location.

Supplementary Table 4 | Principal Components Analysis (PCA) vector Pearson correlation information.

Supplementary Table 5 | DISTLM modeling results to determine the correlations between epifaunal community composition and the environmental variables; coverage of the eight substrate types, seafloor slope and current velocity.

Supplementary Table 6 | Results of the SIMPER analysis showing the cumulative contribution of the principal epifaunal species to the communities observed at the survey locations (Lerresfjorden, Bekkarfjorden 1 and 2, Rosenby, and Klubbnesvika).

aquaculture in fjord systems. ICES J. Mar. Sci. 73, 2408-2419. doi: 10.1093/ icesjms/fsw027

Beisiegel, K., Darr, A., Zettler, M. L., Friedland, R., Gräwe, U., and Gogina, M. (2018). Understanding the spatial distribution of subtidal reef assemblages in the southern Baltic Sea using towed camera platform imagery. Estuar. Coast. Shelf Sci. 207, 82-92. doi: 10.1016/j.ecss.2018.04.006

Boertmann, D., Mosbech, A., Schiedek, D., and Johansen, K. (eds) (2009). The Eastern Baffin Bay. A Preliminary Strategic Environmental Impact Assessment of Hydrocarbon Activities in the KANUMAS West Area. NERI Tech Rep No 720. Roskilde: National Environmental Research Institute, Aarhus University.

Bourdaud, P., Gascuel, D., Bentorcha, A., and Brind'Amour, A. (2016). New trophic indicators and target values for an ecosystem-based management of fisheries. Ecol. Indic. 6, 588-601. doi: 10.1016/j.ecolind.2015.10.010

Bowden, D. A., Rowden, A. A., Leduc, D., Beaumont, J., and Clark, M. R. (2016). Deep-sea seabed habitats: do they support distinct mega-epifaunal communities that have different vulnerabilities to anthropogenic disturbance? Deep Sea Res. 107, 31-47. doi: 10.1016/j.dsr.2015.10.011

Buhl-Mortensen, L., Buhl-Mortensen, P., Dolan, M. F. J., Dannheim, J., Bellec, V., and Holte, B. (2012). Habitat complexity and bottom fauna composition 
at different scales on the continental shelf and slope of northern Norway. Hydrobiologia 685, 191-219. doi: 10.1007/s10750-011-0988-6

Buhl-Mortensen, L., Burgos, J. M., Steingrund, P., Buhl-Mortensen, P., Ólafsdóttir, S. H., and Ragnarsson, S. Á (2019). Vulnerable Marine Ecosystems (VMEs): Coral and sponge VMEs in Arctic and sub-Arctic waters-Distribution and Threats, Vol. 2019519. Copenhagen: Nordic Council of Ministers.

Buhl-Mortensen, P., and Buhl-Mortensen, L. (2014). Diverse and vulnerable deepwater biotopes in the Hardangerfjord. Mar. Biol. Res. 10, 253-267. doi: 10.1080/ 17451000.2013.810759

Buhl-Mortensen, P., Buhl-Mortensen, L., and Purser, A. (2017). “Trophic ecology and habitat provision in cold-water coral ecosystems," in Marine Animal Forests, eds S. Rossi, L. Bramanti, A. Gori, and C. Orejas (Cham: Springer).

Burd, B., Macdonald, T., and Bertold, S. (2013). The effects of wastewater effluent and river discharge on benthic heterotrophic production, organic biomass and respiration in marine coastal sediments. Mar. Pollu. Bull. 74, 351-363. doi: 10.1016/j.marpolbul.2013.06.029

Callaway, R., Alsvåg, J., De Boois, I., Cotter, J., Ford, A., Hinz, H., et al. (2002). Diversity and community structure of epibenthic invertebrates and fish in the North Sea. ICES J. Mar. Sci. 59, 1199-1214. doi: 10.1006/jmsc.2002.1288

Cathalot, C., Van Oevelen, D., Cox, T. J., Kutti, T., Lavaleye, M., Duineveld, G., et al. (2015). Cold-water coral reefs and adjacent sponge grounds: hotspots of benthic respiration and organic carbon cycling in the deep sea. Front. Mar. Sci. 2:37. doi: $10.3389 /$ fmars.2015.00037

Christie, H., Norderhaug, K. M., and Fredriksen, S. (2009). Macrophytes as habitat for fauna. Mar. Ecol. Prog. Ser. 396, 221-233. doi: 10.3354/meps08351

Clarke, K. R., and Gorley, R. N. (2015). PRIMER v7: User Manual/Tutorial PRIMER-E. Plymouth: PRIMER-E.

Clarke, K. R., and Warwick, R. M. (2001). A further biodiversity index applicable to species lists: variation in taxonomic distinctness. Mar. Ecol. Prog. Ser. 216, 265-278. doi: 10.3354/meps216265

Connor, D., Allen, J., Golding, N., Howell, K., Lieberknecht, L., Northern, K., et al. (2004). The Marine Habitat Classification for Britain and Ireland. Report No. ISBN 186107561 8. Naraina: The Institute of Estuarine and Coastal Studies (IECS).

Elith, J., and Leathwick, J. R. (2009). Species distribution models: ecological explanation and prediction across space and time. Annu. Rev. Ecol. Evol. Syst. 40, 677-697. doi: 10.1146/annurev.ecolsys.110308.120159

ESRI Inc (2018). ArcGIS Pro (Version 2.4.2). Redlands, CA: ESRI Inc.

Evans, D. (2006). The habitats of the European Union Habitats Directive. Biol. Environ. 106B, 167-173. doi: 10.3318/BIOE.2006.106.3.167

Fosså, J. H., Mortensen, P. B., and Furevik, D. M. (2002). The deep-water coral Lophelia pertusa in Norwegian waters: distribution and fishery impacts. Hydrobiologia 471, 1-12. doi: 10.1023/A:1016504430684

Gale, K. S., Hamel, J. F., and Mercier, A. (2013). Trophic ecology of deep-sea Asteroidea (Echinodermata) from eastern Canada. Deep Sea Res. 80, 25-36. doi: 10.1016/j.dsr.2013.05.016

Glud, R. N., Berg, P., Hume, A., Batty, P., Blicher, M. E., Lennert, K., et al. (2010). Benthic $\mathrm{O} 2$ exchange across hard-bottom substrates quantified by eddy correlation in a sub-Arctic fjord. Mar. Ecol. Prog. Ser. 417, 1-12. doi: 10.3354/ meps08795

Guisan, A., and Thuiller, W. (2005). Predicting species distribution: offering more than simple habitat models. Ecol. Lett. 8, 993-1009. doi: 10.1111/j.1461-0248. 2005.00792.x

Guisan, A., and Zimmermann, N. E. (2000). Predictive habitat distribution models in ecology. Ecol. Model. 135, 147-186. doi: 10.1016/S0304-3800(00)00 354-9

Haidvogel, D. B., Arango, H., Budgell, W. P., Cornuelle, B. D., Curchitser, E., Lorenzo, E., et al. (2008). Ocean forecasting in terrain-following coordinates: formulation and skill assessment of the regional ocean modeling system. J. Comput. Phys. 227, 3595-3624. doi: 10.1016/j.jcp.2007.06.016

Hamoutene, D., Salvo, F., Bungay, T., Mabrouk, G., Couturier, C., Ratsimandresy, A., et al. (2015). Assessment of finfish aquaculture effect on Newfoundland epibenthic communities through video monitoring. N. Am. J. Aquac. 77, 117-127. doi: 10.1080/15222055.2014.976681

Hamoutene, D., Salvo, F., Donnet, S., and Dufour, S. C. (2016). The usage of visual indicators in regulatory monitoring at hard-bottom finfish aquaculture sites in Newfoundland (Canada). Mar. Pollut. Bull. 108, 232-241. doi: 10.1016/j. aquaculture.2016.08.026
Harris, P. T., and Whiteway, T. (2009). High seas marine protected areas: benthic environmental conservation priorities from a GIS analysis of global ocean biophysical data. Ocean Coast. Manage. 52, 22-38. doi: 10.1016/j.ocecoaman. 2008.09.009

Hogg, M. M., Tendal, O. S., Conway, K. W., Pomponi, S. A., van Soest, R. W. M., Gutt, J., et al. (2010). Deep-sea Sponge Grounds: Reservoirs of Biodiversity. UNEP-WCMC Biodiversity Series No. 32. Cambridge, MA: UNEP-WCMC.

Howell, K. L., Piechaud, N., Downie, A. L., and Kenny, A. (2016). The distribution of deep-sea sponge aggregations in the North Atlantic and implications for their effective spatial management. Deep Sea Res. 115, 309-320. doi: 10.1016/j.dsr. 2016.07.005

Husa, V., Kutti, T., Sævik, P. N., Keeley, N. B., Buhl-Mortensen, P., and Dunlop, K. M. (2019). Kunnskapsstatus Blomkålkorallforekomst ved Husevågøy. Bergen: Institute of Marine Research Internal Report.

ICES (2009). Report of the ICES-NAFO Working Group on Deep-water Ecology (WGDEC), 9-13 March 2009, ICES CM 2009/ACOM:23. Copenhagen: ICES.

Jentoft, S., and Buanes, A. (2005). Challenges and myths in Norwegian coastal zone management. Coast. Manage. 33, 51-165. doi: 10.1080/08920750590

Jonsson, L. G., Nilsson, P. G., Floruta, F., and Lundälv, T. (2004). Distributional patterns of macro-and megafauna associated with a reef of the cold-water coral Lophelia pertusa on the Swedish west coast. Mar. Ecol. Prog. Ser. 284, 163-171. doi: 10.3354/meps 284163

Kamenos, N. A., Moore, P. G., and Hall-Spencer, J. M. (2004). Maerl grounds provide both refuge and high growth potential for juvenile queen scallops (Aequipecten opercularis L.). J. Exp. Mar. Biol. Ecol. 313, 241-254. doi: 10.1016/ j.jembe.2004.08.007

Kershner, J., Samhouri, J. F., James, C. A., and Levin, P. S. (2011). Selecting indicator portfolios for marine species and food webs: a Puget Sound case study. PLoS One 6:e0025248. doi: 10.1371/journal.pone.0025248

Klitgaard, A. B., and Tendal, O. S. (2001). "Ostur -sponge dominated areas in Faroese shelf and slope areas," in Marine Biological Investigations and Assemblages of Benthic Invertebrates from the Faroese Islands, eds G. Bruntse and O. S. Tendal (Faroe Islands: Kaldbak Marine Biological Laboratory), 13-21.

Klitgaard, A. B., and Tendal, O. S. (2004). Distribution and species composition of mass occurrences of large-sized sponges in the northeast Atlantic. Prog. Oceanogr. 61, 57-98. doi: 10.1016/j.pocean.2004.06.002

Knudby, A., Kenchington, E., and Murillo, F. J. (2013). Modeling the distribution of Geodia sponges and sponge grounds in the Northwest Atlantic. PLoS One 8:e82306. doi: 10.1371/journal.pone.0082306

Kutti, T., Bannister, R. J., and Fosså, J. H. (2013). Community structure and ecological function of deep-water sponge grounds in the Traenadypet MPANorthern Norwegian continental shelf. Cont. Shelf Res. 69, 21-30. doi: 10.1016/ j.csr.2013.09.011

Kutti, T., Bannister, R. J., Fosså, J. H., Krogness, C. M., Tjensvoll, I., and Søvik, G. (2015). Metabolic responses of the deep-water sponge Geodia barretti to suspended bottom sediment, simulated mine tailings and drill cuttings. J. Exper. Mar. Biol. Ecol. 473, 64-72. doi: 10.1016/j.jembe.2015.07.017

Lacharité, M., and Metaxas, A. (2017). Hard substrate in the deep ocean: how sediment features influence epibenthic megafauna on the eastern Canadian margin. Deep Sea Res. 126, 50-61. doi: 10.1016/j.dsr.2017.05.013

Long, R. (2011). The marine strategy framework directive: a New European approach to the regulation of the marine environment, marine natural resources and marine ecological services. J. Energy Nat. Resour. Law 29, 1-44. doi: 10.1080/02646811.2011.11435256

Magurran, A. E., and McGill, B. J. (eds) (2011). Biological Diversity: Frontiers in Measurement and Assessment. Oxford: Oxford University Press.

Maldonado, M., Aguilar, R., Bannister, R. J., Bell, J. J., Conway, K. W., Dayton, P., et al. (2017). "Sponge grounds as key marine habitats: a synthetic review of types, structure, functional roles, and conservation concerns," in Marine Animal Forests: The Ecology of Benthic Biodiversity Hotspots, eds L. Bramanti, A. Gori, C. Orejas, and S. Rossi (Cham: Springer), 145-183.

Meyer, H. K., Roberts, E. M., Rapp, H. T., and Davies, A. J. (2019). Spatial patterns of arctic sponge ground fauna and demersal fish are detectable in autonomous underwater vehicle (AUV) imagery. Deep Sea Res. 153:103137. doi: 10.1016/j. dsr.2019.103137

Miller, R. J., Hocevar, J., Stone, R. P., and Fedorov, D. V. (2012). Structure-forming corals and sponges and their use as fish habitat in Bering Sea submarine canyons. PLoS One 7:e33885. doi: 10.1371/journal.pone.0033885 
Mineur, F., Jorge Assis, F. A., Davies, A. J., Engelen, A. H., Fernandes, F., Malta, E. J., et al. (2015). European seaweeds under pressure: consequences for communities and ecosystem functioning. J. Sea Res. 98, 91-108. doi: 10.1016/ j.seares.2014.11.004

Olsen, J., Carter, N. A., and Dawson, J. (2019). Community perspectives on the environmental impacts of Arctic shipping: case studies from Russia, Norway and Canada. Cogent Soc. Sci. 5:1609189. doi: 10.1080/23311886.2019.1609 189

Piechaud, N., Hunt, C., Culverhouse, P. F., Foster, N. L., and Howell, K. L. (2019). Automated identification of benthic epifauna with computer vision. Mar. Ecol. Prog. Ser. 615, 15-30. doi: 10.3354/meps12925

Plotkin, A., Gerasimova, E., and Rapp, H. T. (2018). Polymastiidae (Porifera: Demospongiae) of the Nordic and Siberian Seas. J. Mar. Biol. Assoc. UK 98, 1273-1335. doi: 10.1017/S0025315417000285

Przeslawski, R., Althaus, F., Clark, M., Colquhoun, J., Gledhill, D., Flukes, E., et al. (2018). "Marine sampling field manual for benthic sleds and bottom trawls [Version 1]," in Field Manuals for Marine Sampling to Monitor Australian Waters, Version 1, eds R. Przeslawski and S. Foster (Canberra: NESP Marine Biodiversity Hub), 153-171.

Ramirez-Llodra, E., Trannum, H. C., Evenset, A., Levin, L. A., Andersson, M., Finne, T. E., et al. (2015). Submarine and deep-sea mine tailing placements: a review of current practices, environmental issues, natural analogs and knowledge gaps in Norway and internationally. Mar. Pollut. Bull. 97, 13-35. doi: 10.1016/j.marpolbul.2015.05.062

Ribeiro, S. M., Omena, E. P., and Muricy, G. (2003). Macrofauna associated to Mycale microsigmatosa (Porifera, Demospongiae) in Rio de Janeiro State, SE Brazil. Estuar. Coast. Shelf Sci. 57, 951-959. doi: 10.1016/S0272-7714(02)0 0425-0

Riemann-Zürneck, K. (1994). Taxonomy and ecological aspects of the subarctic sea anemones Hormathia digitata, Hormathia nodosa and Allantactis parasitica (Coelenterata, Actiniaria). Ophelia 39, 197-224. doi: 10.1080/00785326.1994. 10429544

Ross, R. E., Wort, E. J., and Howell, K. L. (2019). Combining distribution and dispersal models to identify a particularly Vulnerable Marine Ecosystem. Front. Mar. Sci. 6:574. doi: 10.3389/fmars.2019.00574

Salvo, F., Mersereau, J., Hamoutene, D., Belley, R., and Dufour, S. C. (2017). Spatial and temporal changes in epibenthic communities at deep, hard bottom aquaculture sites in Newfoundland. Ecol. Indic. 76, 207-218. doi: 10.1016/j. ecolind.2017.01.019
Salvo, F., Oldford, V., Bungay, T., Boone, C., and Hamoutene, D. (2018). Guide for Video Monitoring of Hard Bottom Benthic Communities of the South Coast of Newfoundland for Aquaculture Impact Assessments. Canadian Data Report of Fisheries and Aquatic Science. Fs 97-13/1284E-PDF. Newfoundland: Fisheries and Aquatic Science.

Schöttner, S., Hoffmann, F., Cárdenas, P., Rapp, H. T., Boetius, A., and Ramette, A. (2013). Relationships between host phylogeny, host type and bacterial community diversity in cold-water coral reef sponges. PLoS One 8:e55505. doi: 10.1371/journal.pone.0055505

Shchepetkin, A. F., and McWilliams, J. C. (2005). The regional oceanic modeling system (ROMS): a split-explicit, free-surface, topography-following-coordinate oceanic model. Ocean Model. 9, 347-404. doi: 10.1016/j.ocemod.2004.08.002

Sirenko, B., Denisenko, S., Deubel, H., and Rachor, E. (2004). Deep Water Communities of the Laptev Sea and Adjacent Parts of the Arctic Ocean. Fauna and Ecosystems of the Laptev Sea and Adjacent Deep Waters of the Arctic, Part I. St.-Petersburg: ZIN RAS, 28-73.

Skarð̋hamar, J., Albretsen, J., Sandvik, A. D., Lien, V. S., Myksvoll, M. S., Johnsen, I. A., et al. (2018). Modelled salmon lice dispersion and infestation patterns in a sub-arctic fjord. ICES J. Mar. Sci. 75, 1733-1747. doi: 10.1093/icesjms/fsy035

Tjensvoll, I., Kutti, T., Fosså, J. H., and Bannister, R. J. (2013). Rapid respiratory responses of the deep-water sponge Geodia barretti exposed to suspended sediments. Aquat. Biol. 19, 65-73. doi: 10.3354/ab00522

UN (1992). United Nations Convention on Biological Diversity. New York, NY: UN. Wahl, M. (ed.) (2009). Marine Hard Bottom Communities. Berlin: Springer-Verlag. Wenner, E. L., Knott, D. M., Van Dolah, R. F., and Burrell, V. G. Jr. (1983). Invertebrate communities associated with hard bottom habitats in the South Atlantic Bight. Estuar. Coast. Shelf Sci. 17, 143-158. doi: 10.1016/0272-7714(83) 90059-8

Conflict of Interest: The authors declare that the research was conducted in the absence of any commercial or financial relationships that could be construed as a potential conflict of interest.

Copyright (c) 2020 Dunlop, Harendza, Plassen and Keeley. This is an open-access article distributed under the terms of the Creative Commons Attribution License (CC BY). The use, distribution or reproduction in other forums is permitted, provided the original author(s) and the copyright owner(s) are credited and that the original publication in this journal is cited, in accordance with accepted academic practice. No use, distribution or reproduction is permitted which does not comply with these terms. 